\title{
Effect of Organic Manures and Liming on Post Harvest Grain Quality Parameters and Protein Concentration of Upland Rice in North Eastern India
}

\author{
Bisworanjita Biswal $^{1 *}$, Subhash Babu', Rajeswari Das ${ }^{2}$ and Moutusi Tahasildar ${ }^{3}$ \\ ${ }^{1}$ Division of Agronomy, ICAR-Indian Agricultural Research Institute, New Delhi, India \\ ${ }^{2}$ Department of Soil Science, Dr Rajendra Prasad Central Agricultural University, \\ Pusa Samastipur, Bihar, India \\ ${ }^{3}$ Division of Crop Science, ICAR-Research Complex for NEH Region, \\ Umiam, Meghalaya, India \\ *Corresponding author
}

\section{A B S T R A C T}

\begin{tabular}{|l|}
\hline K e y w o r d s \\
Organic manures, \\
Pig manure, Crude \\
protein, Hulling, \\
Milling, Protein \\
yield, Glutelin
\end{tabular}

Rice the most important staple food in India. Declining soil fertility and high soil acidity is the major concern for low production in North-East India. The present study focuses on the effect of organic manures and liming on post harvest grain quality parameters and protein concentration of upland rice in North Eastern Hill Region of India. The experiment was conducted on mid-altitude hill terrace with Two factors as: Factor A: N0- Control, N1- 100\% RDN through inorganic means, N2- 100\% RDN through FYM, N3- 50\%RDN through FYM + 50\% RDN through Vermicompost (VC), N4- 50\% RDN though FYM + $50 \%$ RDN through Poultry manures (PM) and N5- 50\% RDN though FYM+50\%RDN through Pig Manures (SM). Each level of factor A was alternated with factor B: L0- No Lime and L1- Lime $\left(400 \mathrm{kgha}^{-1}\right) .50 \% \mathrm{FYM}+50 \% \mathrm{SM}$ had maximum grain yield $(3.98$ $\mathrm{t} / \mathrm{ha}$ ) that is $1.5 \%, 7.2 \%$, and $9.6 \%$ higher over $50 \% \mathrm{FYM}+50 \% \mathrm{PM}, 50 \% \mathrm{FYM}+50 \%$ VC and $100 \%$ FYM respectively. 50\% FYM + 50\% SM was $2.9 \%$ significantly high in protein concentration over $50 \% \mathrm{FYM}+50 \% \mathrm{VC}$. There was no promising effect of lime application on post harvest grain quality, protein concentration and yield of upland rice may be due to under application of lime. Therefore, it can be concluded that organic manure practices can be recommended to the farmers of Meghalaya and lime must be applied based on soil test value and not blanket recommendation.

\section{Introduction}

Rice (Oryza sativa L.) is the most staple food in Asia where production and consumption accounts for more than $90 \%$. Brown rice contains $76 \%$ carbohydrate, $7.5 \%$ protein, $1.9 \%$ fat, $0.9 \%$ crude fibre, thiamine, riboflavin, niacin, tocopherol, 32mg calcium, $221 \mathrm{mg}$ phosphorous, 9mg potassium and $1.6 \mathrm{mg}$ iron per $100 \mathrm{~g}$ (Kumar et al., 2007). The burgeoning human population has shrinked the per capita land area from 0.17ha in 1990 to 0.11 in 2016 (World Bank, 2016). This has put immense pressure on limited land area 
and has resorted to indiscriminate fertilizer use. The present food grain production is 296.65 MT (4 ${ }^{\text {th }}$ adv est. 2019-20, MoA and FW). Excessive and imbalanced chemical fertilizer use to achieve the target food grain production in India 333 MT by 2050 has also led to several other concerning direct and indirect effects on man, animal and environment. Malnutrition, biomagnification, eutrophication, green house gas emission, etc. are to name a few of the adverse effect of injudicious application of chemical fertilizers without knowing the actual plant need. On the other hand, organic manure though bulky and required in huge amount has incredible and long term benefits both on living beings and environment. India has the highest livestock population in the world 535.78 million $\left(20^{\text {th }}\right.$ livestock census, 2019). North East region of India is again leading in pig population 9.06 million pigs. North East India were people have now started depending on chemical fertilizers is still somewhere unscathed by chemical pollution making it suitable for witnessing immediate effect of organic agriculture. Manures in every house is available in ample amount as the major source of livelihood is agriculture and animal husbandry.

Cultivation practices using organic manures improves soil water holding capacity, bulk density, soil organic matter, soil organic carbon, improves nutrient retention and availability, minimizes nutrients loss, increases microbial population, soil enzymatic activities, etc. (Wang et al., 2020). Organic manure application enhances plant growth and yield and plays a crucial role in maintaining soil fertility and crop productivity (Chand et al., 2006)). Moreover, tropical region soils are low in organic matter due to faster decomposition of organic matter. High temperature of tropics is responsible for rapid decomposition of organic matter and use of organic matter will help in long-term maintenance of soil organic carbon content
(Gomaa et al., 2015).

North Eastern region of India is among the wettest places on earth receiving more than the average rainfall of the country. Therefore, it is also very low in $\mathrm{pH}$ due leaching of soluble bases. $\mathrm{pH}$ of less than 4.0 is also reported in rice cultivated soils. Hilly topography and highly acidic soils pose constraints in achieving sustainable yield in this region. The contribution of North East region to total rice production is merely $5.9 \%$ i.e. 5.50 million tonnes from $7.8 \%$ of total rice growing area in the country (Singh et al., 2001). Insufficient application of lime and organic manure is costing poor farmers in terms of low yield. Organic manure and lime also serves as soil amendment and raises the $\mathrm{pH}$ to neutral condition, enhances activity of microorganisms and releases plant fixed plant nutrients. There is not much information available on combined use of organic manures and lime on upland rice situation. Therefore, the current study focuses on the use of locally available organic mature and lime on upland rice grain quality in North Eastern India.

\section{Materials and Methods}

The experiment was taken up in kharif 2018 at ICAR-Research Complex for North Eastern Hill Region, Barapani, Meghalaya under upland rice situation in FRBD design. The local rulling medium duration variety Bhalum 3 was taken. Two factors as: Factor A: N0- Control, N1- $100 \%$ RDN through inorganic means, N2- $100 \% \mathrm{RDN}$ through FYM, N3- 50\% RDN through FYM $+50 \%$ RDN through Vermicompost (VC), N4- 50\% RDN though FYM + 50\% RDN through Poultry manures (PM) and N5- 50\%RDN though FYM+50\%RDN through Pig Manures (SM). Each level of factor A was alternated with factor B: L0- No Lime and L1- Lime $\left(400 \mathrm{kgha}^{-1}\right)$. The N, P, K content of organic manures used were FYM-0.5\%, 0.3\%, 0.5\%; 
$\mathrm{VC}-3.5 \%, 1.2 \%, 2.0 \%$; PM $3.5 \%, 3.0 \%$, $3.0 \%$ and SM- 4.2\%, $2.9 \%, 3.8 \%$ respectively. The effect of the above mentioned organic manure combination treatments on grain quality parameters (percentage of hulling, milling and head rice recovery), crude protein content (CPC), protein yield $\left(\mathrm{kgha}^{-1}\right)$ and grain yield $\left(\mathrm{kgha}^{-1}\right)$ were determined using suitable procedures mentioned below.

\section{Hulling}

Hulling percentage was estimated from properly sun dried $100 \mathrm{~g}$ of samples brown rice from each plot which were hulled in a mini 'Satake Rice Mill' followed by recording of the weight of rice. Hulling percentage was computed as:

Hulling $(\%)=[$ Weight of brown rice $(\mathrm{g}) \times 100] /[$ Weight of rough rice $(\mathrm{g})]$

\section{Milling}

Following hulling process, the brown rice was passed through a miller 'Satake Rice Whitening and Caking' Machine for 2 minutes to obtain uniformly polished white rice. The polished rice was weighed and milling percentage was calculated as:

Milling $(\%)=[$ Weight of milled rice $(\mathrm{g}) \times 100] /[$ Weight of rough rice $(\mathrm{g})$ ]

\section{Head rice recovery}

The milled rice was sieved to separate whole kernels from the broken ones. Small proportion of whole kernels which passed along with broken ones was hand separated. Head rice recovery (\%) was computed as:

Head rice recovery $(\%)=[$ Weight of whole rice $(\mathrm{g}) \times 100] /[$ Weight of rough rice]

\section{Crude protein content (\%)}

Crude protein content in grain was calculated by multiplying $\mathrm{N}$ concentration with a factor 5.95 (Juliano, 1985). This factor is based on the nitrogen content $(16.8 \%)$ of the major rice protein glutelin.

\section{Protein yield $\left(\mathrm{kg} \mathrm{ha}^{-1}\right)$}

Protein yield was calculated by multiplying the crude protein content $(\%)$ with grain yield $(\mathrm{kg} / \mathrm{ha})$ and expressed as $\mathrm{kg} / \mathrm{ha}$.

\section{Grain yield ( $\mathrm{kg} \mathrm{ha}^{-1}$ )}

Plot wise crop was harvested after maturity and sun-dried for three days in the field. After threshing, cleaning and drying the grain yield was recorded and reported at $14 \%$ moisture content.

\section{Results and Discussion}

\section{Hulling, milling, head rice recovery}

There was no significant effect of organic manures and liming on hulling parameter of rice. However, 50\% FYM $+50 \%$ SM had significantly higher milling percentage over $100 \%$ inorganic by $10 \%$. $50 \% \mathrm{FYM}+50 \%$ SM had maximum milling percentage and was at par with 50\% FYM + 50\% PM, 50\% FYM $+50 \%$ VC, $100 \%$ FYM and control. In case of head rice recovery $100 \%$ FYM was highest at $63.5 \%$ at par with $50 \%$ FYM + $50 \% \mathrm{PM}(63.4 \%)$ and 50\% FYM + 50\% SM (62.6\%). 100\% FYM was significantly higher over control and $100 \%$ inorganic by $14.6 \%$ and $15.4 \%$ respectively. There was no significant effect of liming on milling and head rice recovery of rice (Table 1 ).

\section{Protein Concentration and protein yield}

The protein concentration was least in control (6.16\%) followed by $100 \%$ FYM $(7.30 \%)$ and highest in $50 \% \mathrm{FYM}+50 \% \mathrm{SM}(7.72 \%)$. $50 \% \mathrm{FYM}+50 \% \mathrm{SM}$ was $2.9 \%$ significantly high over $50 \% \mathrm{FYM}+50 \%$ VC. $50 \% \mathrm{FYM}+$ $50 \% \mathrm{SM}, 50 \% \mathrm{FYM}+50 \% \mathrm{PM}$ and $100 \%$ inorganic were at par with each other. However, effect of lime was not seen on protein concentration. 
Protein yield followed the similar trend as protein concentration with $50 \% \mathrm{FYM}+50 \%$ $\mathrm{SM}(307 \mathrm{~kg} / \mathrm{ha})$ yielding highest protein and control yielding least protein $(201 \mathrm{~kg} / \mathrm{ha})$. $50 \%$ FYM $+50 \%$ SM was significantly higher over $50 \% \mathrm{FYM}+50 \%$ VC by $10.4 \%$ (Table 1).

\section{Grain yield}

Significantly higher grain yield was by nutrient sources over control (3.27 t/ha). The organic manures were at par in grain yield with $100 \%$ inorganic (3.93 t/ha). However, organic manures $50 \%$ FYM $+50 \%$ SM had maximum grain yield (3.98 t/ha) that is $1.5 \%$, $7.2 \%$, and $9.6 \%$ higher over $50 \% \mathrm{FYM}+50 \%$ $\mathrm{PM}, 50 \% \mathrm{FYM}+50 \% \mathrm{VC}$ and $100 \% \mathrm{FYM}$ respectively. Grain yield did not report any significant increase due to application of lime (Table 1).

Table.1 Effect various nutrient sources on post harvest quality parameters and protein concentration of upland rice

\begin{tabular}{|c|c|c|c|c|c|c|}
\hline Treatment & $\begin{array}{l}\text { Hulling } \\
(\%)\end{array}$ & $\begin{array}{l}\text { Milling } \\
(\%)\end{array}$ & $\begin{array}{l}\text { Head rice } \\
\text { recovery } \\
(\%)\end{array}$ & $\begin{array}{l}\text { Protein } \\
\text { conc. }(\%)\end{array}$ & $\begin{array}{l}\text { Protein } \\
\text { yield } \\
\text { (kg/ha) }\end{array}$ & $\begin{array}{l}\text { Grain } \\
\text { yield (t/ha) }\end{array}$ \\
\hline \multicolumn{7}{|l|}{ Sources of Manure (A) } \\
\hline Control & 78.6 & 65.6 & 55.4 & 6.16 & 201 & 3.27 \\
\hline $100 \%$ inorganic & 77.3 & 63.6 & 55.0 & 7.68 & 301 & 3.93 \\
\hline $100 \%$ FYM & 81.0 & 69.7 & 63.5 & 7.30 & 264 & 3.63 \\
\hline $50 \%$ FYM + 50\% VC & 78.6 & 67.3 & 58.6 & 7.50 & 278 & 3.71 \\
\hline $50 \%$ FYM + 50\% PM & 79.1 & 69.8 & 63.4 & 7.63 & 299 & 3.92 \\
\hline $50 \%$ FYM + 50\% SM & 79.1 & 70.0 & 62.6 & 7.72 & 307 & 3.98 \\
\hline $\operatorname{SEm}( \pm)$ & 2.01 & 2.12 & 2.11 & 0.04 & 3.58 & 0.15 \\
\hline $\mathrm{CD}(\mathrm{P}=\mathbf{0 . 0 5})$ & NS & 6.15 & 6.02 & 0.11 & 10.48 & 0.44 \\
\hline \multicolumn{7}{|l|}{ Lime (B) } \\
\hline No Lime & 78.8 & 67.7 & 60.1 & 7.31 & 258 & 3.53 \\
\hline Lime (400 kg ha $\left.{ }^{-1}\right)$ & 79.1 & 67.7 & 59.4 & 7.35 & 275 & 3.75 \\
\hline $\operatorname{SEm}( \pm)$ & 1.87 & 1.22 & 1.21 & 0.02 & 2.72 & 0.14 \\
\hline $\mathrm{CD}(\mathrm{P}=0.05)$ & NS & NS & NS & NS & 7.96 & NS \\
\hline
\end{tabular}

The protein content was higher in organic manures due to higher nitrogen content. Application of organic manures led to better soil physico-chemical and biological properties that improved nutrient retention in soil, increased plant nutrient uptake and consequent accumulation in tissues (Basak et al., 2020). Availability of plant nutrients particularly nitrogen which is most susceptibility to environmental losses, is enhanced and extended over a long period of time due to plant need based mineralization of organic manures (Das et al., 2020). Organic manures improve soil rhizosphere conditions and enhance nutrient acquisition. This promotes plant growth, development and yield. High protein yield is the result of high yield and high protein concentration (Heba et al., 2016). Protein concentration in inorganic treatment was at par with $50 \%$ FYM $+50 \%$ $\mathrm{SM}$ and $50 \% \mathrm{FYM}+50 \% \mathrm{PM}$ may be due easily mineralizable nitrogen from fertilizers. Organic manure treated plots received balanced nutrition throughout growing period and the grains were less chaffy and had less breakage. However, hulling, milling, and head 
rice recovery are largely varietal characters and depend on several factors such as drying conditions, grain type, storage, and milling conditions(Witte, 1972). There was no promising effect of lime application on post harvest grain quality, protein concentration and yield of upland rice may be due to under application of lime. The amount of lime applied was recommended dose for Meghalaya but, condition of soil and acidity varies from location to location. Therefore, it is assumed that the amount of lime applied was insufficient to bring the soil $\mathrm{pH}$ to neutral condition and can help in achieving long term sustainability.

In conclusion the organic manure practices can be recommended to the farmers of Meghalaya where every household has an animal unit especially piggery instead of relying on complete inorganic agriculture. Soil test based lime application must be done instead of applying blanket recommendation. Organic manures use in long term can help us achieve higher profit due to its better grain quality and sustain the soil and environment health in North Eastern Himalayan region of India.

\section{Acknowledgements}

The authors are grateful to ICAR-IARI, Division of Agronomy for their cooperation and funding during the field study.

\section{References}

World

Bank, 2016 https://tradingeconomics.com/india/ara ble-land-hectares-per-person-wbdata.html

DoES. 2018-19. $3^{\text {rd }}$ Advance Estimate of Food grains, Oilseeds and other Commercial crops https://eands.dacnet.nic.in/Advance_E stimate/1st\%20Adv.\%20Estimates202
0-21\%20English.pdf

$20^{\text {th }}$ livestock Census. 2019. Ministry of Agriculture Department of Animal Husbandry, Dairying and Fisheries, Government of India. All India Report.

Kumar, A., Staal, S. J., Elumalai, K., and Singh, D. K. (2007). Livestock sector in north-eastern region of India: An appraisal of performance. Agricultural Economics Research Review, 20(3472016-16637), 255-272.

Singh, S. B., Sarma, B. K., Goswami, S. N., Dutta, K. K., and Singh, K. B. (2001). Production and productivity Analysis of rice in North-East India. Indian $J$. Hill Farmg, 14(1), 39-44.

Wang, X., Yan, J., Zhang, X., Zhang, S., and Chen, Y. (2020). Organic manure input improves soil water and nutrients use for sustainable maize (Zea mays. L) productivity on the Loess Plateau. Plos one, 15(8), e0238042.

Chand, S., Anwar, M., and Patra, D. D. (2006). Influence of long-term application of organic and inorganic fertilizer to build up soil fertility and nutrient uptake in mint-mustard cropping sequence. Communications in Soil Science and Plant Analysis, 37(1-2), 63-76.

Gomaa, M. A., Radwan, F. I., Kandil, E. E., and Gharib, A. F. (2015). Effect of nitrogenous sources and zinc application method on productivity and quality of rice (Oryza sativa L.). Middle East J. Applied Sci, 4, 913-919.

Basak, B. B., Saha, A., Sarkar, B., Kumar, B. P., Gajbhiye, N. A., and Banerjee, A. (2020). Repurposing distillation waste biomass and low-value mineral resources through biochar-mineralcomplex for sustainable production of high-value medicinal plants and soil quality improvement. Science of The Total Environment, 143319. 
Basak, B. B., Saha, A., Sarkar, B., Kumar, B. P., Gajbhiye, N. A., and Banerjee, A. (2020). Repurposing distillation waste biomass and low-value mineral resources through biochar-mineralcomplex for sustainable production of high-value medicinal plants and soil quality improvement. Science of The Total Environment, 143319.

Noman, H. M., Rana, D. S., Choudhary, A. K., Rajpoot, S., and Paul, T. (2016). Sulphur and $\mathrm{Zn}$ management in groundnut (Arachis hypogaea)-wheat (Triticum aestivum) cropping system: Direct effects on system productivity and residual effects on yield, energetics and $\mathrm{Zn}$ biofortification in wheat. Indian Journal of Agricultural Sciences, 86(4), 441-7.

Witte, G.C. 1972. Conventional rice milling in the United States. Rice Chemistry and Technology. American Association Cereal Chemist Incorporation, St. Paul, pp. 188-200.

\section{How to cite this article:}

Bisworanjita Biswal, Subhash Babu, Rajeswari Das and Moutusi Tahasildar. 2020. Effect of Organic Manures and Liming on Post Harvest Grain Quality Parameters and Protein Concentration of Upland Rice in North Eastern India. Int.J.Curr.Microbiol.App.Sci. 9(12): 144149. doi: https://doi.org/10.20546/ijcmas.2020.912.019 